\title{
Explanation and Social Theory
}

\section{M. Holmwood \& A. Stewart}

Londres, Macmillan, 1991

- Por Roberto Venosa, Engenheiro, Mestre em Administraçăo Pública pela Universidade de Pittsburgh, Doutor em Sociologia pela EHESS, Paris, professor Titular do Departamento de Administraçäo Geral e Recursos Humanos da EAESPJFGV e professor visitante da University of St. Andrews, Escócia.

$\mathrm{E}$ m 14 de novembro de 1991, encontrei pela primeira vez "Sandy" Stewart. Era um daqueles dias que anunciavam o inverno, dia claro, porém, um frio de rachar. Combinamos almoçar juntos, pois eu estava interessado em conversar com Robert Blackburn, amigo de Sandy, que leciona Sociologia em Cambridge. $\mathrm{Na}$ conversa, durante o almoço, Sandy e eu discutiriamos a melhor maneira de falar com "Bob".

Eu ainda não havia me encontrado pesscalmente com Sandy. Somente havíamos falado ao telefone. Logo de início, Sandy revelou-se uma pessoa fascinante, simples, inteligente, humilde e, acima de tudo, leva a vida que eu gostaria de levar. Sandy foi Sentor Lecturer em Cambridge tendo trabalhado e publicado $\mathrm{com}$ Runciman, Giddens, Blackburn entre outros. Mais tarde, assumitu a cátedra de Sociologia na Universidade de Edinburgh, chateou-se com a mesquinharia universitária (o que na Escócia é pleonasmo), abandonou a cátedra e, hoje, tem a "Marckinsh Wine Gallery", mora em Ansthruter, pequena vila de pescadores, e ensina Sociologia na Universidade de St. Andrews. Ou seja, Sandy especializou-se em vinhos e em Sociologia.

Demorei-me na introdução pois, muitas vezes, a gente se anima com as pessoas e perde o senso critico. Como veremos, näo perder o senso crítico é um aspecto importante na leitura do livro de Sandy e Holmwood.

Sandy estava desapontado com a Sociologia. Para ele, critica-se o positivismo sem romper com ele; louva-se a ação racional e torna-se prisioneiro dela. Por estas e outras razöes, Sandy e Holmwood resolveram publicar Explanation and Social Theory.

Olivro encontra-se dividido em nove capítulos e uma conclusão. Os capítulos principais, no entanto, vão do $4^{\circ}$ ao $9^{\circ}$. As criticas ao positivismo (capítulo 2 ) e ao relativismo (capitulo 3), embora úteis, não se distanciam do que já se conhece. Quando Sandy e Holmwood discutem as falácias horizontais e verticais, realmente, entram no assunto. A falácia vertical é melhor exemplificada pelo reducionismo marxista e pelas inúmeras tentativas de manter-se a análise das estruturas sociais presa ao modo de produção. A falácia horizontal é mais interessante, mesmo porque mais atual. Para os autores, quando os neoweberianos criticam os marxistas (falácia vertical) eles, sem perceber, caem na falácia horizontal.

Para exemplificar o que estão pretendendo dizer, os autores apóiam-se na análise de David Lockwood sobre as diferenças de status entre os clercks no Reino Unido. Os autores demonstram que Lockwood, quando näo dá conta das especificidades e das diferenças internas, comete a falácia horizontal. Tentemos, atraveés de outro exemplo, clarear um pouco mais. Suponhamos que estejamos preocupados $\mathrm{com}$ a seguinte questão: quais as possibilidades de um discurso profissional?

Em um primeiro nivel de análise, os marxistas responderiam que o discurso profissional deve ser visto como um instrumento de dominação das classes baixas (Braverman, 1974). Os neoweberianos, ao criticarem os marxistas, neomarxistas, protomarxistas e os marxistas encarcerados ou fundamentalistas, procuram buscar a especificidade dos grupos intermediários e as formas de discurso que esses grupos estrategicamente utilizam. Entre esses discursos, encontramos os discursos profissionais. Para os neoweberianos, a razão dos experts é, ao mesmo tempo, a esperteza da razão (Hollis, 1982). Assim, Villette, ao examinar a reprodução das classes dominantes, percebe que as classes altas mantêm seu poder, pela transformação de capital social em competência rara, ou seja, freqüentando as melhores escolas e dispondo de uma melhor dotação de capital social, os herdeiros possuem, ao mesmo tempo e como corolário, maiores chances de acesso às posições dominantes $e$ ao conhecimento inovador marginalmente escassos. Mas será que a tese de Villette é suficiente? Qual a razäo de o discurso profissional ter mais espaço na sociedade americana que na sociedade britânica ou na francesa? Para Sandy e Holmwood, esta é a falácia horizontal. Segundo os autores, na crítica aos marxistas, os neoweberianos sucumbem à falácia horizontal ou, como Saturno, tomam-se vítimas de sua própria criaçăo. Em breve, a afirmação de Villette, embora verdadeira, não responde à questão: quais as possibilidades de um discurso profissional?

Para os autores, seria necessário proceder-se a outro recorte; por exemplo, examinar-se a taxa de expansäo das elites e, simultaneamente, examinarem-se as tendências à proliferação ou enxugamento das posiçōes de 
mando. Na confluência dessas duas séries seria possível observarem-se as condiçốes e possibilidades de discursos profissionais específicos. Acima de tudo, o que Sandy e Holmwood estảo propondo é uma postura perante a vida. $O$ desencantamento weberiano deve ser o instrumento fundamental do cientista ao olhar a sociedade, a sua própria obra e, talvez, a sí mesmo.

Retomando a introdução desta resenha, Sandy continua sendo uma pessoa cativante, porém, ao propor uma critica ao "estabelecimento" sociologico, os autores sucumbem às duas falácias pois não vâo além da crítica.

A teoria da ação que emerge na leitura do livro revela-se no fazer sociologico que, ao descobrir, também transforma o mundo. Ao longo de capítulos onde são aprofundadas as contradiçoes entre racionalidade e açã̃o, ação e estrutura, poder e ordem normativa, estrutura e função, falsá consciência e alienação ontológica, os autores descobrem a perpetuação de falácias horizontais e verticais na obra de diversos cientistas sociais (Parsons, Giddens, Habermas), porém, não vão além da crítica, como eles próprios reconhece:

"Não temos metodologia para oferecer, nem rotinas para criativamente resolver problemas. A soluçno de problemas origina novos dados e novas relaçóes. Metodologias são resultados de práticas atuais e estão baseadas em esquemas que precisam ser transformados ao mesmo tempo que os problemas sia solucionados. Precisamos de nowos 'olhares' sociológicos $e$ nào de novas regras metodológicas. Tudo que podemos fazer é orientar os cientistas sociats para problemas que requerem a energia criativa deles..."

Em resumo, se Mozart ficasse somente criticando Salieri, possivelmente teríamos a mais lúcida e extensa crítica de Salieri, mas não teríamos Don Giovanni nem a Missa da Coroação.

O livro de Sandy e Holmwood ê de dificil leitura. porém, é um manual necessário para o aprendizado do trabalho intelectual ao se caminhar ao encontro da saborosa descoberta da indeterminaçăo da natureza e/ou da vida social, e não de encontro ao misterioso rigor do conhecimento competente sobre a natureza $\mathrm{e} /$ ou sobre as relações sociais

\section{BIBLIOGRAFIA}

BRAVERMAN, H. Labour and Monopoly Capitalism. New York, Monthly Review Press, 1974.

HOLLIS, M. "The Social Destruction of Reality". In: HOLLIS, M. \& LUKES, S. (orgs.) Rationality and Relatizism, Oxford, Basil Blackwell, 1982.

\section{Reestruturação Urbana: Tendências e Desafios}

\section{Licia Valladares e Edmond Pretecelle}

São Paulo, NOBELIUPERJ, 1990, 227 páginas.

Por Leonor M. Cámara, Socióloga, Mestre em Administração Pública e Planejamento, doutoranda em Administraçăo na EAESP/FGV, pesquisadora do CEDEC (Centro de Estudos e Cultura Contemporânea), professora da FEA/PUC/SP.

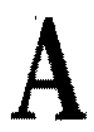
tualmente vivenciamos uma crise do processo de acumulação capitalista, haja vista a recessão nos Estados Unidos da América e o tatcherismo na Inglaterra, para citar apenas alguns exemplos. Simultaneamente, vivenciamos um processo de grandes transformaçōes urbanas que vêm ocorrendo em escala mundial, incluindo aí o redimensionamento do papel do urbano e da região na economia. $O$ desenvolvimento da tecnologia e as telecomunicações são indicadores desse processo e resultam na abertura das cidades aos mercados internacionais. A cidade e a regiáo não estão mais limitadas pelo espaço físico. Como resultado, podemos observaro surgimento de problemas urbanos em cidades localizadas em países desenvolvidos que até há pouco pensávamos serem específicos de cidades de países do Terceiro Mundo, como os problemas da habitação e degradaçăo urbana, por exemplo. A partir dessas constataçoes, os coordenadores da presente obra, Edmond Preteceille e Lícia Valladares, colocam as seguintes indagaçōes: Pode-se atribuir as transformaçōes 